\title{
MANAGEMENT STRATEGY OF OIL PALM WASTE IN ENVIRONMENTAL DEVELOPMENT EFFORTS
}

\author{
Kusrini Novira*, Sulistiawati Rini, Imelda \\ University of Tanjungpura, Indonesia \\ *E-mail: novira k@yahoo.co.id
}

\begin{abstract}
The research aims to know the management priority of oil palm empty fruit bunches (EFB). Selecting the best management strategy of EFB in the environmental development efforts is an important issue. This issue is one of the most critical steps for Crude Palm Oil (CPO) factories since it will potentially bring environmental pollution if not properly managed. In the methodology, initially, the hierarchy tree diagram is constructed, which includes the criteria and sub-criteria considered and some alternatives that will be selected to be the best management strategy. In addition, a questionnaire is developed for pair-wise comparison and to collect opinion from oil palm farmers, managers of CPO factory, practitioners and academics. The relative importance of the measurement criteria are assessed using the Analytical Hierarchy Process approach. The result indicated that the highest priority of management strategy of EFB is as the mushroom planting media supported by the aspect of market performance. The second priority is as the compost for oil palm to produce the superior one from the aspect of financial performance and environmental aspect.
\end{abstract}

\section{KEY WORDS}

Management, compost, mushrooms, planting.

The oil palm industry in West Kalimantan is one of the fastest growing industries and is projected to remain a priority in the plantation sector in the future. The development of the agro-industry sector in general and the oil palm plantation in particular have a negative impact on the increasing amount of waste. According to Chavalparit et al. (2006), the wastes produced from oil palm plantations and factories are liquid waste, solid waste, and gas waste. The waste management of oil palm industry needs to have serious attention because it is a sensitive global issue in sustainable development (Hendaru, 2013). Thus, it will potentially bring negative impact on the oil palm industry if not properly managed. (Hendra et al, 2014).

West Kalimantan as one of the largest oil palm producers in Indonesia should seek technologies that can increase the added value of these wastes, especially if considering the positive impacts on environmental carrying capacity and the reduction of pollution burden. Therefore, the friendly environmental management technology strategy of oil palm that is sustainable from the upstream, oil palm fresh fruit bunches (FFB) production, up to CPO (Crude Palm Oil) production at the processing factory, needs to be immediately applied by the oil palm industry (Indriantoro et al., 2012).

Solid waste is the focus of this research because the following ones: (1) in the production process of CPO, EFB is the largest waste that is about $22-23 \%$ of FFB (Stella, et al.2016, Hayashi, 2007, Widiastuti and Panji, 2007), (2) EFB has double functions those are besides adding the nutrients to the soil, it also increases the content of soil organic matter indispensable for the improvement of soil physical properties (Department of Agriculture, 2006), (3) EFB has not been optimally utilized by most Oil Palm mills (Palamae et al., 2017) although the quantity of this waste is very abundant (Y.P Olisa and K.W. Kotingo, 2014).

Based on the data from West Kalimantan Plantation Office, in 2016 there are 61 CPO factories in West Kalimantan that need 2055 tons of FFB per hour. This means that the activities of the CPO factories will produce EFB about $46,237.5$ tons per hour, which is a waste that until now cannot be handled optimally. This amount will continue to increase with the increase of FFB production in West Kalimantan. This certainly creates new problems to 
the environment, especially the emergence of environmental pollution and waste treatment that is quite costly if the management of this waste is not immediately handled.

Researches on the processing and management of oil palm waste have been largely conducted, one of which is by Mailinton (2007) and Fibrian, et al (2010), but researches on management of oil palm waste, especially in West Kalimantan, has not been conducted yet. According to the Ministry of Agriculture (2006), the alternative management of EFB conducted at the farmer level like mulch on the plantation land functions as a soil enhancer and helps reduce the less good impact on plant growth and production during the dry season. However, the application of mulch requires high operational costs (transportation); therefore, to minimize the operational costs, most of the oil palm mills do not pay attention to the ways of applying a good mulch (Deva, et al., 2010). This may lead to the emergence of the oil palm pests that will inhibit the productivity of oil palm crops (Weng and Kandiah, 2007).Therefore, the alternative management of EFB as mulch is not the best solution.

Other potential in the management of EFB is as the compost (Dahyar, 2010, Sarwono, 2008) and mushroom planting media (Tabi, et al., 2008; Hidayati et al., 2015 and Kavitha B., 2013 ) is also an alternative that needs to be considered because each has advantages in technical management. The selection of the best alternative method will be used as the strategy for the future in the management of EFB in order that the increasing quantity of EFB can be handled properly so that the negative impact can be minimized and it simultaneously can realize the environmental development.

\section{METHODS OF RESEARCH}

The research method used is survey method, which was conducted in April-July 2016 in the area of Korek Village, Sungai Ambawang District. The primary data in this research was obtained through direct interviews, direct observation, and questionnaires. Questionnaires are designed for data collection from 20 respondents. They are oil palm farmers, managers of CPO factory, practitioners and academics. The secondary data was obtained from the internal and external data from companies, the Bureau of Plantation West Kalimantan, previous researches, and various literatures related to this research.

This research uses AHP (Analytical Hierarchy Process) approach that aims to formulate the priority of management strategy of EFB. AHP method is the best solution for multi-criteria decision making (Saaty, 1993; Reisinger et al., 2003; Clinton et al., 2002) and has a practical and effective approach that may consider the uncomplicated and complicated decisions (Partovi and Hopton, 1994).

The steps in performing AHP include:

1. Determining the objectives based on the existing problems in order to determine the priority of the management strategy of oil palm empty bunches.

2. Creating a hierarchical structure that begins with a general objective, followed by sub-objectives, criteria, and possible alternatives at the bottom of the criteria level.

3. Creating a pair wise comparison matrix describing the relative contribution or influence of each element on each of the above objectives or criteria. The comparisons are based on the judgment of decision makers by assessing the importance level of an element over other elements. The value of comparison scale in AHP can be seen in table 1.

4. Disseminating questionnaires to a number of respondents / assessors. If a pair wise comparison assessment is conducted by a voting (independent) by each appraiser, the result of individual appraisal should be processed first into the combined opinion matrix. Because in this study the assessment is conducted by consensus, it is not necessary for the processing of compound opinions, because the opinions that appear have been the combined opinions of the assessors.

5. Developing a matrix of the combined opinions obtained from the interviews of respondents and then performing data processing using expert choice 11.0.

6. Assessing inconsistencies and priorities. If the consistency value is more than 0.10 , the result is inconsistent; but if the consistency value is less than 0.10 , the result is 
consistent. Based on these results, the prioritized criteria and alternatives can be known (Marimin, 2004).

7. Determining priority scale of criteria and alternatives for achieving hierarchical variables with the objective of management strategy of EFB.

Table 1 - Value of Comparison Scale in AHP

\begin{tabular}{cl}
\hline Value & \\
\hline 1 & A is as important as B \\
3 & A is a little more important than B \\
5 & A is exactly more important than B \\
7 & A is so exactly more important than B \\
9 & A is absolutely more important than B \\
$2,4,6,8$ & If being doubtful between two close values \\
$1 / 3$ & (A compared to B) \\
$1 / 5$ & B is more important than A \\
$1 / 7$ & B is a little more important than A \\
$1 / 9$ & B is exactly more important than A \\
$1 / 2,1 / 4,1 / 6,1 / 8$ & B is absolutely more important than A \\
& If being doubtful between two close values \\
\end{tabular}

Source: Saaty, 1993.

Formulation of Criteria and Hierarchy. Hierarchy I of this AHP is to determine the alternative management strategy of EFB as priority. The criteria used in this research are partly adopted from the criteria used by the Technology Audit Center (Subiyanto, 2013) using technical-technological and business criteria. (i) Technical-technological criteria is to see the needs, technological requirements, and operational constraints particularly in relation to the environment-friendly environment faced by the managers, in this case the oil palm farmers for each management strategy of EFB and their relation to the quality and quantity of output generated. (ii) Business criteria is to see the prospect of the three types of technology in terms of cost-benefit and also other strategic considerations related to business continuity. Because the business continuity needs to see the market opportunity that constantly change and the selling price of product produced to fit its resource and to fulfill the expected profit targets, in logical consequence, the analysis in this research needs one criteria that is market criteria.

In the second hierarchy, criteria are established affect the final objectives, including criteria: (1) tool performance, (2) financial performance, (3) technology image, and (4) market performance. Some considerations considered to be the reason in determining these four criteria in determining the priority of the management strategy of EFB in hierarchy II include:

1. Tool performance: This criterion is considered to have objective and definitive data. The relevant sub-criteria are tool efficiency and tool practicality that is an important factor, especially when the farmers should decide in adopting a technology. This is in line with the opinion of Herman et al. (2006), which stated that one of the influencing factors in technology adoption is the simplicity of technology that can be seen from the tool practicality.

2. Financial performance: Tool performance criteria must be balanced with financial criteria for business purposes. It means that the selection of the management system needs to consider the reality of the palm oil farmers' ability in providding investment funds for equipment procurement, low operational costs, and calculation of the rate of return on investment.

3. Technology image: There are more palm oil industry players and also the oil palm farmers who have opportunity to utilize EFB for free, which makes the competition in utilizing EFB increase. In the competitions in getting the labors, the minimal environmental impacts arise from the handling system, and the current technology becomes a necessity. Therefore, the technology image needs to be considered as a criterion in the selection of management strategy of EFB.

4. Market performance: For the oil palm farmers who will increase the profits by selling the products produced, the market performance is also a very important point. Therefore, the 
market performance is also the next criterion that will be analyzed into sub-criteria of distribution and price stability. This is in line with the opinion of Pratama and Sahaya (2014), which also incorporated the marketing criterion in the preparation of soybean development strategy in Indonesia.

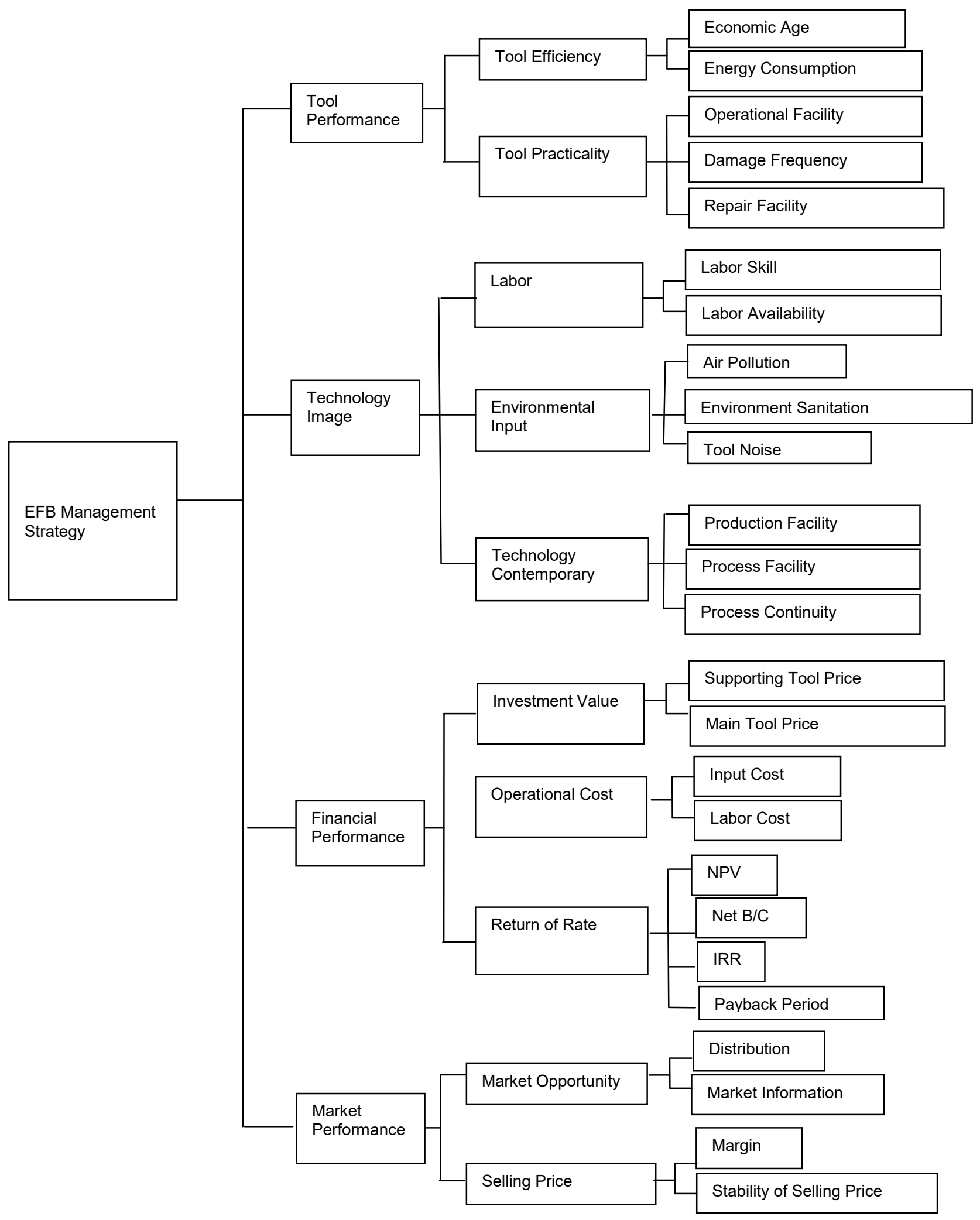

Figure 1 - Decision Hierarchy Structure 
Hierarchy III is the sub-criteria that have the same direct relationship with the above elements (hierarchy II). The number of sub-criteria is not the same for each criterion. Hierarchy II is an incomplete hierarchy (not all sub-criteria at its lower level has a direct relationship, for example, the tool performance criterion has no direct relationship with the investment value sub-criteria), then the comparison in hierarchy III is conducted only to subcriteria that have the same direct relationship with the above elements (hierarchy II). Similarly with hierarchy III, hierarchy IV is also the sub-criteria that have a direct relationship similar to the above element, in this case is hierarchy III. Hierarchy IV is also an incomplete hierarchy. In hierarchy $\mathrm{V}$, an assessment is conducted by calculating the relative performance of each technology system from the point of view of the sub-criteria existing in hierarchy IV. Because there are 25 sub-criteria in hierarchy IV and the hierarchy is complete, there are 25 sets of pairwise comparison.

Based on the description of the final objectives, criteria, and sub-criteria, and also the alternative technology strategy to be chosen, the overall framework of the decision hierarchy structure is as shown in Figure 1.

\section{RESULTS AND DISCUSSION}

Description of EFB Management System. The process of managing EFB, especially the compost for nursery and mushroom media, requires pressure (steam) energy and demands reliable equipment. Inaccuracy in the supply of enumeration machines and the process of grinding EFB that are not in accordance with the needs will affect the results of products to be produced and ultimately affect the operational costs, processing capacity, and quality of the resulting product. Comparison of EFB management system is presented in table 2 below.

Table 2 - Comparison of Management System of EFB

\begin{tabular}{|c|c|c|c|c|}
\hline \multirow[b]{2}{*}{ No } & \multirow[b]{2}{*}{ Parameter } & \multicolumn{3}{|c|}{ Management System of EFB (1 ton capacity) } \\
\hline & & Nursery Compost & $\begin{array}{l}\text { Productive Plant } \\
\text { Compost }\end{array}$ & Mushroom Plant Media \\
\hline 1 & $\begin{array}{l}\text { Tool } \\
\text { Efficiency }\end{array}$ & $\begin{array}{l}\text { Efficient enough (the } \\
\text { milling process is } \\
\text { enough to be conducted } \\
\text { once) }\end{array}$ & Efficient & $\begin{array}{l}\text { Less efficient (the grinding process } \\
\text { with enumerator machine is } \\
\text { conducted twice) }\end{array}$ \\
\hline 2 & $\begin{array}{l}\text { Tool } \\
\text { Operation }\end{array}$ & Difficult & $\begin{array}{l}\text { Relatively easy (without } \\
\text { using machines, only } \\
\text { tools commonly used) }\end{array}$ & $\begin{array}{l}\text { Relatively difficult to operate the } \\
\text { machine enumerator (because the } \\
\text { system is relatively new among the } \\
\text { oil palm farmers) }\end{array}$ \\
\hline 3 & $\begin{array}{l}\text { Investment } \\
\text { Value (IDR) }\end{array}$ & $\begin{array}{l}\text { Tool machine of EFB } \\
\text { enumerator costs IDR } \\
9,000,000\end{array}$ & $\begin{array}{l}\text { Tarpaulin tool, sprayer, } \\
\text { hoe, and so on cost } \\
\text { IDR } 5,100,000\end{array}$ & $\begin{array}{l}\text { Tool machine of EFB enumerator } \\
\text { costs IDR } 9,000,000 \\
\text { Making mushroom house costs IDR } \\
7,510,000\end{array}$ \\
\hline 4 & $\begin{array}{l}\text { Operational } \\
\text { Price (IDR) }\end{array}$ & IDR $6,585,000$ & IDR 2,400,000 & IDR $8,400,000$ \\
\hline 5 & $\begin{array}{l}\text { Rate of } \\
\text { Return }\end{array}$ & $\begin{array}{l}\text { Net Present Value = } \\
915,086 \\
\text { Net } B / C=1.06 \\
\text { IRR }=14.48 \\
\text { Payback Period }=2.36 \\
\text { years }\end{array}$ & $\begin{array}{l}\text { NPV }=21,214,866 \\
\text { Net } B / C=5.16 \\
\text { IRR }=142.04 \\
P P=1.68 \text { years }\end{array}$ & $\begin{array}{l}\text { NPV }=16,293,463 \\
\text { Net } B / C=1.99 \\
\text { IRR }=47.40 \\
\text { PP }=1.94 \text { years }\end{array}$ \\
\hline 6 & $\begin{array}{l}\text { Process } \\
\text { Continuity }\end{array}$ & Continue & Continue & Continue \\
\hline 7 & Processing & Relatively easy & Easy & Difficult \\
\hline 8 & $\begin{array}{l}\text { Labor } \\
\text { Availability }\end{array}$ & Relatively easy & Easy & More selective \\
\hline 9 & $\begin{array}{l}\text { Market } \\
\text { Opportunity }\end{array}$ & Relatively difficult & Relatively easy & Easy \\
\hline 10 & $\begin{array}{l}\text { Selling price } \\
\text { (IDR /kg) }\end{array}$ & IDR 22,000 & IDR 15,000 & IDR 70,000 \\
\hline
\end{tabular}

Source: primary data processed (2016). 
Priority of Criteria in the formulation of EFB Management Strategy. Based on the priority weighting results in all sub criteria and criteria, the Consistency Ratio (CR) is below $10 \%$. This indicates that the results of the assessment are consistent and thus qualify for continued processing. Based on AHP Hierarchy II, the market performance aspect is the most important criterion in formulating the management strategy of EFB with the largest weight value of 0.656 (table 3 ). This shows that the oil palm industry needs to consider the market aspect in the formulation of EFB management strategy. This is in line with the research of Jumna (2015), Santoso and Marimin (2001) and Oelviani (2013), which stated that marketing is the most important criterion to be considered in the agricultural development.

The second priority criterion to consider next in the formulation of EFB management strategy is financial performance with a weight value of 0.218 (Table 3). Economic factors (financial-costs) are always considered in the investors' decision making in business (Sameh M. Saad et al, 2016, Majid and Nemat, 2015). In other words, the selection of a management system needs to consider the costs to be incurred in implementing the technology. If the application of a technology requires a high cost, it will be difficult in technical implementation. Based on previous studies, one of the obstacles of technology adoption is that innovation / technology is so expensive that makes the farmers difficult to spend capital in the adoption of such technology (Musyafak, et al., 2002). So the placement of financial performance criterion into the second priority in the formulation of EFB management strategy is very precise and acceptable from the economic side.

Table 3 - Criteria of Management of EFB at Hierarchy II

\begin{tabular}{llll}
\hline No. & Criteria & Weight Value & Order of Priority \\
\hline 1. & Tool Performance & 0.078 & 3 \\
2. & Financial Performance & 0.218 & 2 \\
3. & Technology Image & 0.048 & 4 \\
4. & Market Performance & 0.656 & 1 \\
\hline Ratio of Consistency: 0.07 & & \\
\hline
\end{tabular}

Source: primary data processed (2016).

Table 4 - Criteria of Market Performance

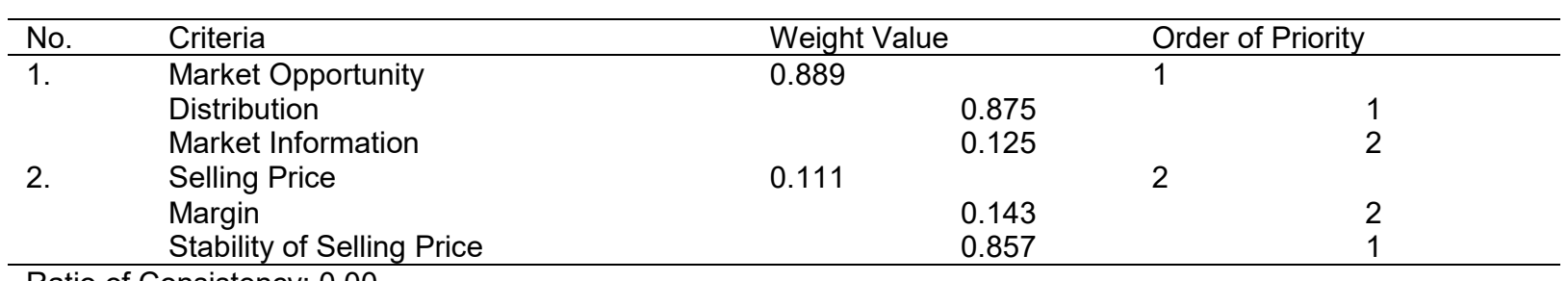

Ratio of Consistency: 0,00

Source: primary data processed (2016).

Table 5 - Criteria of Financial Performance

\begin{tabular}{|c|c|c|c|c|c|}
\hline \multirow{2}{*}{$\frac{\text { No. }}{1 .}$} & \multirow{2}{*}{$\begin{array}{l}\text { Criteria } \\
\text { Aspect of Investment Value }\end{array}$} & \multicolumn{2}{|c|}{ Weight Value } & \multicolumn{2}{|c|}{ Order of Priority } \\
\hline & & 0.687 & & 1 & \\
\hline & Supporting Tool Price & & 0.111 & & 2 \\
\hline & Main Tool Price & & 0.889 & & 1 \\
\hline \multirow[t]{3}{*}{2.} & Aspect of Operational Cost & 0.186 & & 2 & \\
\hline & Input Cost & & 0.833 & & 1 \\
\hline & Labor Cost & & 0.167 & & 2 \\
\hline \multirow[t]{5}{*}{3.} & Aspect of Return Rate & 0.127 & & 3 & \\
\hline & NPV & & 0.574 & & 1 \\
\hline & Net B/C & & 0.239 & & 2 \\
\hline & IRR & & 0.056 & & 4 \\
\hline & Payback Period & & 0.131 & & 3 \\
\hline
\end{tabular}

Source: primary data processed (2016). 
The third and fourth priority in the formulation of EFB management strategy is the tool performance with a weight value of 0.078 and the technology image with a weight value of 0.048. Technological factor considerations are also in accordance with the opinion of Masyahoro (2006), which stated that the factors of readiness and quality of technology are very influential in agricultural development.

Table 6 - Criteria of Tool Performance

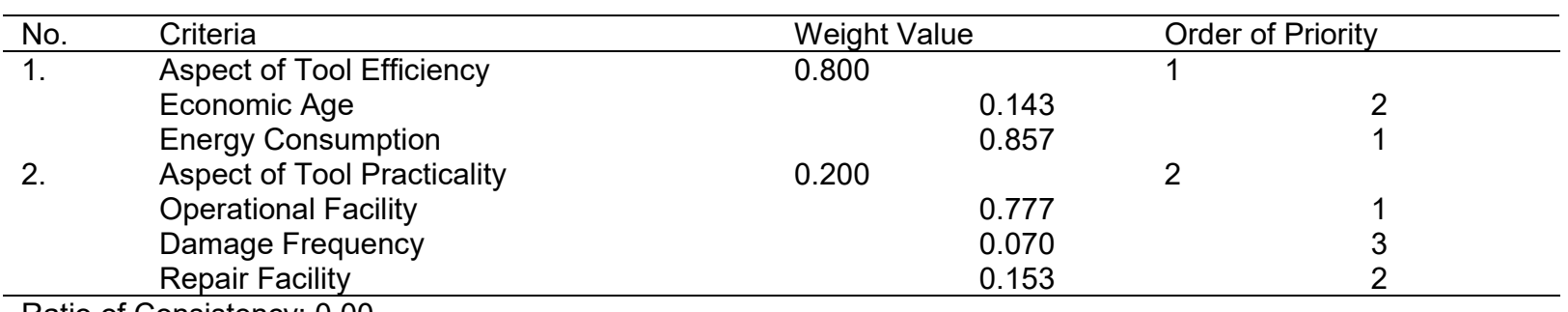

Ratio of Consistency: 0.00

Source: primary data processed (2016).

Table 7 - Criteria of Technology Image

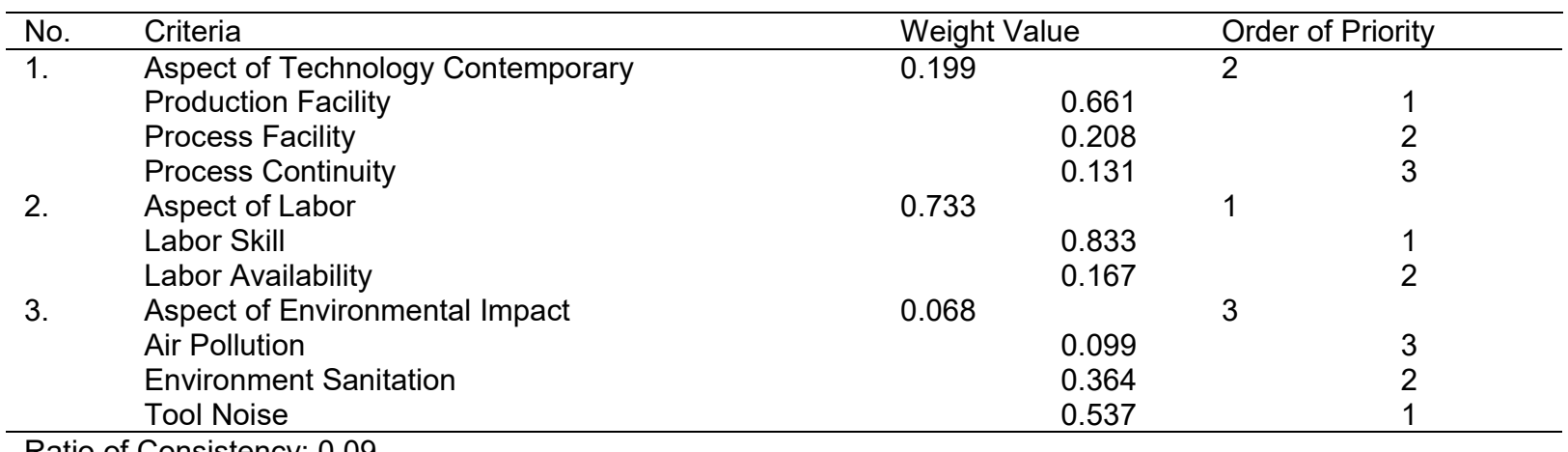

Source: primary data processed (2016).

Determination of the Alternative Priorities of EFB Management Strategy. The results of the overall analysis of the priority scale of criteria and alternative management of EFB using AHP method are shown in table 8. The results show that the management strategy of EFB as the mushroom planting media has the highest priority value with weight value of 0.477 , compared to other strategy choices. In addition, the utilization of EFB as the oyster mushroom planting media has several advantages, including: 1) the abundance of EFB, 2) EFB are already degraded naturally, 3) the mushrooms produced contain high nutrients and can be consumed by the people, and 4) the residual waste of mushroom planting media can be applied as organic fertilizer (Ningtyas and Astuti, 2010). So this strategy is recommended to apply by the company. The second priority strategy is as the compost for productive oil palm with a weight value of 0.336 and the last priority is as the compost for oil palm nursery with a weight value of 0.187 .

Alternative of management strategy of EFB to be mushroom planting media. The determination of EFB management strategy as the mushroom planting media is appropriate because this strategy has a very good performance in terms of the criteria of market performance $(0.638)$ (the highest priority criteria) and technology image $(0.475)$ (second priority) in the second hierarchy. Empty bunches are used as the mushroom planting media. Market opportunity is very promising, which can be seen from the market demand. Market demand criterion is the most important factor in decision-making (Khoirunnisa, et al, 2013). Mushrooms contain high nutrients so the demand is very high, but the existing production has not been able to meet the demand, so it opens the opportunity for oyster mushroom cultivation (Chazali and Putri, 2010). In addition, the selling price for oyster mushrooms may reach IDR $70,000 / \mathrm{kg}$. Consequently, the sub-criterion is in the third 
hierarchy. The management of EFB as the mushroom planting media has a very good performance in terms of market opportunity aspect that has a high leverage weight of 0.705 . In hierarchy IV, market distribution has the highest weight of 0.731 .

However, seen from the sub-criteria of labors at hierarchy III, the management of mushroom planting media requires labors that are more selective because the application of this technology is relatively new in the field, especially in Korek Village. It needs trained people to apply this technology in relation with the operation of enumerators as the main tool used in managing EFB as the mushroom growing media.

This also makes the sub-criteria in hierarchy III, which is the management of EFB as the mushroom growing media, very important to see the aspect of labor $(0,581)$. In hierarchy IV, from 25 sub-criteria being considered, the sub-criterion of labor's expertise (0.731) is an important factor to consider in the mushroom planting media.

Based on these considerations, the selection of mushroom planting media becoming the first priority in the management strategy of EFB is very logical, grounded and in accordance with the facts in the field.

Table 8 - EFB Management Based on Each Criterion and Result of Overall Decision Criteria

\begin{tabular}{|c|c|c|c|c|}
\hline \multirow{2}{*}{ No. } & \multirow{2}{*}{ Criteria } & \multicolumn{3}{|c|}{ Weight Value } \\
\hline & & Nursery Compost & Producing Plant Compost & Mushroom Planting Media \\
\hline \multicolumn{2}{|c|}{ Tool Performance } & 0.239 & $0.629^{*}$ & 0.131 \\
\hline \multirow[t]{3}{*}{1} & Tool Efficiency & 0.251 & $0.603^{*}$ & 0.146 \\
\hline & Economic Age & 0.263 & $0.659^{*}$ & 0.079 \\
\hline & Energy Consumption & 0.249 & $0.594^{*}$ & 0.157 \\
\hline \multirow[t]{4}{*}{2} & Tool Practicality & 0.192 & $0.734^{*}$ & 0.074 \\
\hline & Operation Facility & 0.183 & $0.742^{*}$ & 0.075 \\
\hline & Damage Frequency & 0.353 & $0.586^{*}$ & 0.061 \\
\hline & Repair Facility & 0.166 & $0.761^{*}$ & 0.073 \\
\hline \multicolumn{2}{|c|}{ Financial Performance } & 0.238 & $0.648^{*}$ & 0.115 \\
\hline \multirow[t]{3}{*}{1} & Investment Value & 0.271 & $0.657^{*}$ & 0.073 \\
\hline & Supporting Tool Price & 0.205 & $0.717^{*}$ & 0.078 \\
\hline & Main Tool Price & 0.279 & $0.649^{*}$ & 0.072 \\
\hline \multirow[t]{3}{*}{2} & Operational Cost & 0.254 & $0.636^{\star}$ & 0.110 \\
\hline & Input Cost & 0.268 & $0.614^{*}$ & 0.117 \\
\hline & Labor Cost & 0.183 & $0.742^{*}$ & 0.075 \\
\hline \multirow[t]{5}{*}{3} & Rate of Return & 0.073 & $0.575^{\star}$ & 0.352 \\
\hline & NPV & 0.070 & $0.559^{*}$ & 0.371 \\
\hline & Net B/C & 0.075 & $0.567^{*}$ & 0.357 \\
\hline & IRR & 0.078 & $0.635^{\star}$ & 0.287 \\
\hline & Payback Period & 0.078 & $0.635^{\star}$ & 0.287 \\
\hline \multicolumn{2}{|c|}{ Technology Image } & 0.227 & 0.298 & $0.475^{*}$ \\
\hline \multirow[t]{4}{*}{1} & Technology Contemporary & 0.269 & $0.515^{\star}$ & 0.216 \\
\hline & Production Facility & 0.249 & $0.594^{*}$ & 0.157 \\
\hline & Process Facility & $0.443^{*}$ & 0.387 & 0.169 \\
\hline & Process Continuity & 0.089 & 0.323 & $0.588^{*}$ \\
\hline \multirow[t]{3}{*}{2} & Labor & 0.221 & 0.198 & $0.581^{*}$ \\
\hline & Labor Skill & 0.226 & 0.101 & $0.674^{*}$ \\
\hline & Labor Availability & 0.200 & $0.683^{*}$ & 0.117 \\
\hline \multirow[t]{4}{*}{3} & Environmental Impact & 0.165 & $0.740^{*}$ & 0.095 \\
\hline & Air Pollution & 0.075 & $0.567^{*}$ & 0.357 \\
\hline & Environmental Sanitation & 0.194 & $0.743^{*}$ & 0.063 \\
\hline & Tool Noise & 0.162 & $0.770^{\star}$ & 0.068 \\
\hline \multicolumn{2}{|c|}{ Market Performance } & 0.160 & 0.202 & $0.638^{*}$ \\
\hline \multirow[t]{3}{*}{1} & Market Opportunity & 0.088 & 0.206 & $0.705^{*}$ \\
\hline & Distribution & 0.081 & 0.188 & $0.731^{*}$ \\
\hline & Market Information & 0.140 & 0.333 & $0.528^{*}$ \\
\hline \multirow[t]{4}{*}{2} & Selling Price & $0.733^{*}$ & 0.164 & 0.103 \\
\hline & Margin & $0.661^{*}$ & 0.208 & 0.131 \\
\hline & Selling Price Stability & $0.745^{*}$ & 0.156 & 0.099 \\
\hline & Total & 0.187 & 0.336 & $0.477^{* *}$ \\
\hline
\end{tabular}

Source: primary data processed (2016).

Explanations: * management priority of EFB for each criterion; ${ }^{* *}$ management priority of EFB as a whole. 
Alternative of management system of EFB to be the compost for the productive oil palm crops. Although the management of EFB as the compost for oil palm crops becomes the second priority, however, in terms of the financial performance $(0.648)$ and the tool performance $(0.629)$ at hierarchy II, the performance is best compared to the mushroom planting media and the compost for oil palm nursery.

When assessed from the financial performance for management strategy of composting for oil palm crops, all sub criteria ranging from investment value, operational cost, and return rate at hierarchy III have the best performance. This is proved by the calculation in Table 2. It is known that (i) the investment value in the form of tools, the fund needed for the management of 1 ton EFB is only IDR 5,100,000 (it is far when compared with the cost of tools in this case the counter enumerator of IDR $9,000,000$, plus the cost for the manufacture of mushroom production houses of IDR 7,510,000, (ii) operational cost of composting for oil palm crops produces only requires IDR 2,400,00, which the least among the other managements, (iii) the return rate on investment becomes more feasible because when viewed from the calculation of NPV, Net B / C, IRR and payback period, the resulting value is very good. Consequently, the result of weighting the sub-criteria of investment value, operational cost and the rate of return for compost management for oil palm plantation are the highest at $0.657,0.636,0.575$ compared to the composts for oil palm nursery and mushroom planting media.

The value of investment becomes an important factor in assessing the financial performance, especially for the price of the main tool that is relatively large weight of 0.889 (Table 4.). Moch Amin, et al (2014) also stated the same that the capital costs and the operational costs are important variables in the selection of a technology. This is very reasonable because the higher the price of the main tool is, the longer the payback period (the rate of return on investment) which will lead to lower priority strategy choice.

When assessed from the tool performance, at the strategy management of compost for the producing oil palm crops, all sub-criteria ranging from the tool efficiency and the tool practicality at hierarchy III has the best performance. When viewed from the tool operation, the compost for the productive oil palm crops is relatively easier than that for the palm oil seedling and the mushroom growing media. The tool usage on compost for the productive palm oil is relatively commonly used in the field (Table 2). Consequently, the sub-criteria at hierarchy III, the management of EFB as the compost for oil palm crops has a very good performance in terms of practical aspects of the tool (0.734).

Different from the mushroom planting media, the use of enumerator machine is still relatively new. The frequency of use for the main tool on mushroom planting media that is the enumerator of EFB is much more because it requires twice of milling in order to obtain a fine powder as the mushroom planting media. The high frequency of tool usage will increase the risk of tool damage (Table 2). This is what may cause the tool efficiency to the mushroom planting media less efficient. Based on the consideration of the performance tool side, the compost for the productive oil palm crops is better than the mushroom planting media.

Furthermore, if seen from the sub-criteria at hierarchy III, besides the practicality tool aspect with good performance, the management of EFB as the compost for the productive oil palm crops has also a very good performance in terms of environmental impact with the weight of 0.7040 , which is the highest compared to other alternative management strategies. This is because sub-criteria such as air pollution, environmental sanitation, and noise of tools generated from the selection of compost strategies for the productive oil palm crops is relatively less than others. So it can be said that in terms of environmental sustainable development, this management strategy is most recommended although the sub-criterion of market is neglected.

\section{CONCLUSION}

The important factors in formulating the alternative EFB management strategy are the aspects of market performance (weight value 0.656), financial performance (weight value 0.218 ), tool performance (weight value 0.078 ), and technology image (weight value 0.048). 
An alternative for EFB management strategy for mushroom planting media is the first priority to implement because the market performance is the best compared to other alternative strategies. Although the management strategy as the compost for oil palm crops is the second alternative, from the aspect of financial performance it is superior to other strategies. In addition to environmental aspects, this strategy is also superior.

Therefore, it is advisable for the farmers or managers of oil palm mills to be able to manage EFB as the mushroom planting media by managing other aspects of poor performance, such as financial, labor and environmental aspects. So in the future, this strategy may improve the welfare of the oil palm farmers and the performance of the oil palm mils in West Kalimantan also may realize the environmental development.

\section{REFERENCES}

1. Chavalparit O, Rulkens WH, Mol APJ, Khaodhair S. 2006. Options for environmental sustainability of the crude palm oil industry in Thailand through enhancement of industrial ecosystems. Journal of Environment, Development and Sustainability 8:271-287.

2. Chazali, S. and Putri, S.P. 2010. Oyster Mushroom Business for Household Scale. Jakarta: Penebar Swadaya.

3. Clinton, B.D., Webber, S.A. And Hassell, J.M. (2002) Implementing The Balanced Scorecard Using The Analytic Hierarchy Process, Management Accounting Quarterly, 3(3): 1-11.

4. Dahyar, A. (2010). Waste Management of Oil Palm Bunches and Azola into Tablet Fertilizer Compost. Thesis. Post Graduate School. North Sumatera University, North Sumatera.

5. Agriculture Departement. 2006. Guidelines for Waste Management of Palm Oil Industry. Agriculture Departement. http://www.agribisnis.deptan.go.id. Accessed date, April 25, 2016.

6. Fibrian, Martini, and Marimin. 2007. Decision Support System for Optimizing the Management of Palm Oil Solid Waste. Journal of Industrial Engineering of Agriculture. IPB. Volume 20 (2) hal 13-142.

7. Hayashi Kiichiro. 2007. Environmental Impact of Palm Oil Industry in Indonesia. Proceedings of Interntional Symposium on EcoTopia Scence. . 646 - 651.

8. Hendaru Sadyadharma., A. Rahim Matondang, Zulkifli Nasution, Herman Mawengkang. 2013. Sustainable Production Planning Model Of Crude Palm Oil IndustryUnder Uncertainty. International Journal Of Engineering Research andTechnology (IJERT)2(8). 1100-1105.

9. Hendra Septiawana, Hariyadib, Machmud Thoharic. 2014. Analysis of Environmental Management of Palm Oil Factory Batu Ampar -PT. Smart Tbk in Implementation of Indonesian Sustainable Palm Oil. Journal of Natural Resources and Environmental Management. 4(2): 136-144.

10. Herman, dkk. 2006. Analysis of Factors Affecting the Adoption of Cacao Fruit Disease Control Technology: A Case Study in West Sulawesi. Pelita Perkebunan. 22(3).222-236.

11. Hidayati, Mohamad Rusdi Hidayat and Asmawit.2015. Utilization of Empty Fibers of Palm Oil as a Growing Media of White Oyster Mushroom. Biopropal Industry. 6(2). 73-80.

12. Indriantoro FW, Sa'id EG, Guritno P. 2012. Value Chain of Palm Oil Production. Journal of Management and Agribusiness. 9(2): 108-116.

13. Jumna, Basudewo Krisna. 2015. Strategy of Farming Development in Efforts to Increase Organic Rice Production in Kecamatan Sambirejo Sragen Regency. Economics Development Analysis Journal. 4(3). 256-264.

14. Kavitha, B., G. Rajannan, P. Jothimani. 2013. Utilization Of Empty Fruit Bunch Of Oil Palm As Alternate Substrate For The Cultivation Of Mushroom. International Journal Of Science, Environment And Technology, 2(5); 839 - 846.

15. Khoirunnisa, Haryono and Nugraha. 2013. Revenue Analysis and Decision Making in Determining Superior Vegetable Crops in District Gisting Tanggamus Regency. Journal of Agribusiness Sciences. 1(2).98-104. 
16. Majid Azizi., Nemat Mohebbi. 2015. A strategic model for selecting the location of furniture factories: a case of the study of furniture. International Journal Multicriteria Decision Making, 5(1/2). 87- 108.

17. Marimin, 2004. Decision Making Technique and Applications of Multiple Criteria. Jakarta.

18. Masyahoro, 2006. Development Policy Analysis of Purse Seine Fishery with Analytical Hierarchy Process (AHP) Method in Parigi Moutung. Agroland Journal. 13(3).275-281.

19. Mohd Amin Abd Majid, Zulkipli Ghazali, Nazri Talib Shin Min. 2014. Techno-Economic Evaluation on Enhancing Cogeneration Plant Capacity: Case Study of Palm Oil Mill Cogeberation Plant. Journal of Applied Sciences 14 (3): 285 - 290

20. Musyafak, A. Hazriani, Suyatno, A. Sahari, J and Kilmanun, J.C. 2002. The Impact of Agricultural Technology in West Borneo. Agricultural Technology Assessment Center of West Borneo. Pontianak.

21. Ningtyas, V.A. and Astuti, L.Y. (2010). Utilization of empty palm oil bunches of mushroom media as an organic fertilizer with the addition of EM4 Activator. Essay. Institut Teknologi Sepuluh Nopember, Surabaya.

22. Oelviani, Renie. 2013. Application of AHP Methid to Formulate Strategy of Strengthening Performance of Red Chili Agribusiness System in Temanggung District. Journal of Agricultural Informatics. 22(1).11-19.

23. Partovi F.Y. and W.E. Hopton. 1994. The Analytic Hierarchy as Applied to Two Types of Inventory Problem. Production and Inventory Management Journal. 35(1).13-19.

24. Pratama and Sahaya.2014. Strategy of Developing Soybean Farming System to Realize National Food Security. Economic and Policy Journal. 7(2).100-202.

25. Reisinger, H., Cravens, K.S. And Tell, N. (2003). Prioritizing Performance Measures Within The Balanced Scorecard Framework, Management International Review 43(4):429-437.

26. Saaty, T.L., 1993. Decision Making For Leader: The Analitycal Hierarchy Process for Decision Complex World. PT. Pustaka Binama Pressindo. Jakarta.

27. Sameh M. Saad, Noufal Kunhu AndAbdel M. Mohamed. 2016. A Fuzzy-AHP MultiCriteria Decision-Making Model For Procurement Process .International Journal Logistics Systems And Management, 23 (1): 1-24.

28. Santoso and Marimin, 2001. The determination of Superior Processed Apple Products Using Non Numerical Fuzzy Technique and Structure Analysis and Institutional Development Pattern. Technology and Food Industry Journal.12(2).163-170.

29. Sarwono Edhi, 2008. Management of Empty Bunches as Substitution of Palm Oil Fertilizer. APLIKA Journal. 8(1); $19-23$.

30. Stella Gilbert Temu. 2016. Mixed Palm Oil Waste Utilization through Integrated Mushroom and Biogas Production British Biotechnology Journal 11(4): 1-12.

31. Subiyanto. 2013. Selection of Sterilizer Technology at Palm Oil Mill using AHP Method. Industrial Engineering Journal. 14(2).160-173.

32. Suriya Palamae, Pongsathorn Dechatiwongse, Wanna Choorit, Yusuf Chisti, Poonsuk Prasertsan. 2016. Cellulose and Hemicellulose Recovery from Oil Palm Empty Fruit Bunch (EFB) Fibers And Production Of Sugars From The Fibers. Carbohydrate Polymers 155 (2017) 491-497

33. Tabi, Zakil, Fauzai, Ali and Hassan. 2008. The Usage of Empty Fruit Bunch (EFB) and Palm Pressed Fibre (PPF) as Substrates for the Cultivation of Pleurotus Ostreatus. Jurnal Teknologi. 49(F).189-196.

34. Weng WP and Kandiah S. 2007. Emerging Trends in Palm Oil Milling Technology. in Proceedings of Chemistry and Technology Conference PIPOC2007, Kuala Lumpur. September 31, 2007.

35. Widiastuti and Panji, T. 2007. Management of Empty Fruit Bunches of Mushroom Residues as an Organic Fertilizer in Oil Palm Nurseries. 75(2).70-79. Plantation Biotechnology of Research Center in Indonesia. Bogor.

36. Y.P.Olisa and K.W. Kotingo. 2014. Utilization of Palm Empty Fruit Bunch (PEFB) As Solid Fuel for Steam Boiler. European Journal of Engineering and Technology 2(2): 1-7. 